\title{
Expression of Expansin Gene (CDK-Exp3) and Its Modulation by Exogenous Gibberellic Acid During Ripening and Softening of Persimmon Fruit
}

\author{
Zhengke Zhang \\ College of Horticulture, Northwest A\&F University, Yangling 712100, China; \\ and the Enviroment and Plant Protection Institute, Chinese Academy of \\ Tropical Agricultural Sciences, Danzhou 571737, China
}

Runshan Fu
College of Horticulture, Northwest A\&F University, Yangling 712100, China

Donald J. Huber

Horticultural Sciences Department, P.O. Box 110690, IFAS, University of Florida, Gainesville, FL 32611-0690

Jingping Rao ${ }^{1}$ and Xiaoxiao Chang

College of Horticulture, Northwest A\&F University, Tai-Cheng Road 3, Yangling 712100, China

\author{
Meijiao Hu \\ Enviroment and Plant Protection Institute, Chinese Academy of Tropical \\ Agricultural Sciences, Danzhou 571737, China
}

\section{Yu Zhang and Nina Jiang \\ College of Horticulture, Northwest A\&F University, Yangling 712100, China}

Additional index words. persimmon, expansin, gibberellic acid, $\mathrm{GA}_{3}$, real-time PCR, softening

Abstract. Expansins are proteins that have been reported to contribute to fruit softening. In this study, an expansin gene, $C D K-E x p 3$, was identified from persimmon fruit, and the mRNA accumulation of CDK-Exp3 during postharvest softening was examined using real-time polymerase chain reaction (PCR). Sequence analysis showed that CDK-Exp3 contained a putative open reading frame of 765 bp encoding a polypeptide of 254 amino acid residues, which had all the characteristics of $\alpha$-expansin. As fruit softened, the expression of $C D K-E x p 3$ increased dramatically within the initial 8-day ripening at $20^{\circ} \mathrm{C}$ followed by a gradual decline at the late stages of ripening. The expression of CDK-Exp3 was inhibited by gibberellic acid, and the maximum transcript abundance was delayed by 20 days compared with that of the control fruit. The results suggest that CDK-Exp3 might be closely related to softening of persimmon fruit during postharvest ripening.

'Fupingjianshi' persimmon (Diospyros kaki L.) is one of the important astringent persimmon cultivars in northwest China. The cultivar is very fast to ripen at ambient temperature after harvest. Softening is a very important feature of persimmon fruit ripening, providing juicy and melting textures for edible quality. It has been well known that fruit

Received for publication 17 Nov. 2011. Accepted for publication 9 Jan. 2012.

This work was supported by grants from the National Natural Science Foundation of China (30771756).

Zhengke Zhang and Runshan Fu contributed equally this work.

${ }^{1}$ To whom reprint requests should be addressed; e-mail raojingping@hotmail.com. softening involves depolymerization and solubilization of cell wall components including matrix polysaccharides (hemicellulose and pectins) (Brummell and Harpster, 2001). The final hydrolysis and breakdown of cell wall components result from the action of cell wall hydrolases including polygalacturonase [electrical conductivity (EC) 3.2.1.15], pectin methylesterase (EC 3.1.1.11), $\beta$-galactosidase (EC 3.2.1.23), and xyloglucan endotransglycosylase (EC 2.4.1.207) (Brummell and Harpster, 2001). However, these enzymes may not be individually responsible for disassembly of cell wall polymers because molecular modification of these enzymes has not fully prevented fruit softening in many cases (Goulao and Oliveira, 2008).

Expansins are nonenzymatic cell walllocalized proteins that were first isolated from cucumber hypocotyl walls by analysis of $\mathrm{pH}$ dependent cell-wall extensibility (McQueenMason et al., 1992). Expansins are cell wall proteins without hydrolytic activity and function to loosen hydrogen bonds between cellulose microfibrils and matrix polysacchardes in cell walls, particularly xyloglucans. This results in enhanced accessibility of cell wallmodifying enzymes, accelerating cell wall degradation (Brummell and Harpster, 2001; Li et al., 2003; McQueen-Mason and Cosgrove, 1995; Rose and Bennett, 1999). Numerous studies confirmed that expansins play an important role in fruit softening (Goulao and Oliveira, 2008; Payasi et al., 2009; Rose et al., 1997), as has been shown for a variety of fruits such as tomato (Brummell et al., 1999, 2002; Rose et al., 1997, 2000), strawberry (Civello et al., 1999), peach (Hayama et al., 2003), pear (Hiwasa et al., 2003), mango (Sane et al., 2005), kiwifruit (Yang et al., 2007), banana (Asha et al., 2007), loquat (Yang et al., 2008), and papaya (Gaete-Eastman et al., 2009).

In our previous study, two fragments of expansin genes in persimmon (cv. Fupingjianshi) fruit, termed $C D K-\operatorname{Exp} 1$ and $C D K-\operatorname{Exp} 2$ (not the full length sequences), were cloned during fruit growth and ripening (Tong et al., 2005). The objective of the present study was to identify the cloning for a full-length expansin gene $(C D K-E x p 3)$ at the onset of ripening as well as to investigate the hypothesis that the expansin gene might be involved in persimmon fruit softening by interference of gibberellic acid $\left(\mathrm{GA}_{3}\right)$ on ripening.

\section{Materials and Methods}

Plant material. Persimmon (Diospyros kaki L. cv. Fupingjianshi), an astringent cultivar with $\approx 70 \%$ of surface yellow coloration (ripening initiated) fruit, were harvested from a commercial orchard in Fuping county, Shaanxi Province of China. The fruit were packed in fiberboard cartons and transported to the postharvest facilities in Northwest A\&F University on the day of harvest. Fruit of uniform size without mechanical damage were selected for the experiments.

Gibberellic acid treatment. Persimmon fruit were randomly divided into two treatment groups, 270 fruit for each treatment. One group was immersed in $\mathrm{GA}_{3}$ solution [60 $\mathrm{mg} \cdot \mathrm{L}^{-1}$ of $\mathrm{GA}_{3}$ (Sigma, St. Louis, MO) and Silwet L-77 surfactant (GE Silicones, Wilton, CT) $(0.05 \%, \mathrm{v} / \mathrm{v})]$ for $1 \mathrm{~min}$ at $20^{\circ} \mathrm{C}$. The second group of persimmon treated with distilled water $\left(1 \mathrm{~min}, 20^{\circ} \mathrm{C}\right)$ was used as the control. After $\mathrm{GA}_{3}$ or water treatment, the fruit were wiped dry with paper towels and ripened at $20^{\circ} \mathrm{C}$. Three replicates of five fruit for each treatment were sampled every $4 \mathrm{~d}$ during postharvest storage. Fruit flesh was cut into small slices (seeds were discarded) and frozen in liquid nitrogen. Samples were stored at $-80{ }^{\circ} \mathrm{C}$ for use. The experiments were performed twice with similar results.

Fruit firmness. Firmness was determined using a pressure tester (Model FT327; Effegi, Milan, Italy) equipped with an 8-mm diameter 
probe. For each treatment, two measurements were carried out at two equidistant points on the equatorial axis of 10 fruit. Firmness was expressed as $\mathrm{N} / \mathrm{cm}^{2}$.

Ethylene production. Five fruit from each treatment were individually placed in 3.6-L sealed glass jars for $1 \mathrm{~h}$ at $20^{\circ} \mathrm{C}$, after which gas samples $(1 \mathrm{~mL})$ were collected with a syringe. Ethylene was determined by injecting a gas sample into a flame ionization detection Shimadzu GC-14A gas chromatograph (Shimadzu, Kyoto, Japan). The oven, detector, and injector were operated at 100,120, and $120{ }^{\circ} \mathrm{C}$, respectively. The carrier gas $\left(\mathrm{N}_{2}\right.$, $\mathrm{H}_{2}$, and air) flow rates were 30,30 , and 300
$\mathrm{mL} \cdot \mathrm{min}^{-1}$, respectively. Ethylene production was expressed as $\mathrm{ng} \cdot \mathrm{kg}^{-1} \cdot \mathrm{min}^{-1}$.

Reverse transcription-polymerase chain reaction. Total RNA was extracted from persimmon fruit at 4-d intervals during storage according to the method of Tong et al. (2005). RNA from pulp (without $\mathrm{GA}_{3}$ treatment) at Day 8 of storage was used for cDNA synthesis. cDNA was synthesized using oligo $\mathrm{d}(\mathrm{T})_{18}$ and reverse transcriptase M-MLV (Takara, Dalian, China). Partial cDNA was amplified using a degenerate sense primer (5'-GSNCAYGCNACNTTYAYGGNG-3') and an antisense primer, $\left(5^{\prime}\right.$-YTGCCARTTY TGNCCCCARTT-3') $(\mathrm{N}=\mathrm{A} / \mathrm{C} / \mathrm{G} / \mathrm{T}, \mathrm{Y}=\mathrm{C} / \mathrm{T}$,

Table 1. Primers used in real-time quantitative polymerase chain reaction.

\begin{tabular}{lll}
\hline Target gene & Primer name & Sequences of primers $\left(5^{\prime}-3^{\prime}\right)$ \\
\hline CDK-Exp3 & CDK-Exp3 SP & TCACTGCCACTAACTTCTGC \\
& CDK-Exp3 AP & TCTTATTCCACCCTTTTTCAC \\
CDK-Actin & CDK-Actin SP & GGATTCTGGTGATGGTGTTAG \\
& CDK-Actin AP & CAGCAGTTGTTGTGAAGGAGT \\
\hline
\end{tabular}

$\mathrm{N}=\mathrm{G} / \mathrm{C}, \mathrm{R}=\mathrm{A} / \mathrm{G}$ ), which were designed according to the conserved regions of plant expansin sequences. The PCR product was cloned into pMD-18T vector and sequenced. Using the nucleotide sequence obtained (Sangon Biotech, Shanghai, China), specific internal primers (3'GSP1: TCACTGCCACTAACTTCTGC, 3'GSP2: ATCTTGCTGAGCCTGCCTTCCT; 5'GSP1: TGTTCTGGACCCCTTGACTG, 5'GSP2: GAAGGCAGGCTCAGCAAGAT) were designed for $5^{\prime}$ and $3^{\prime}$ rapid amplification of cDNA ends (RACE) PCR, which were performed using a RACE cDNA Amplification Kit (Takara, Dalian, China) following the instructions of the supplier. The two PCR products reconstituted a composite cDNA of 1168 bp according to the sequencing result (Sangon Biotech, Shanghai, China). Based on sequence of composite cDNA, upstream (5'-AATATGG CCAATCCTGCAAC $-3^{\prime}$ ) and downstream (5'-CAGCGATAGACTCTCAATGC-3') primers were synthesized to amplify the fulllength expansin gene including the complete
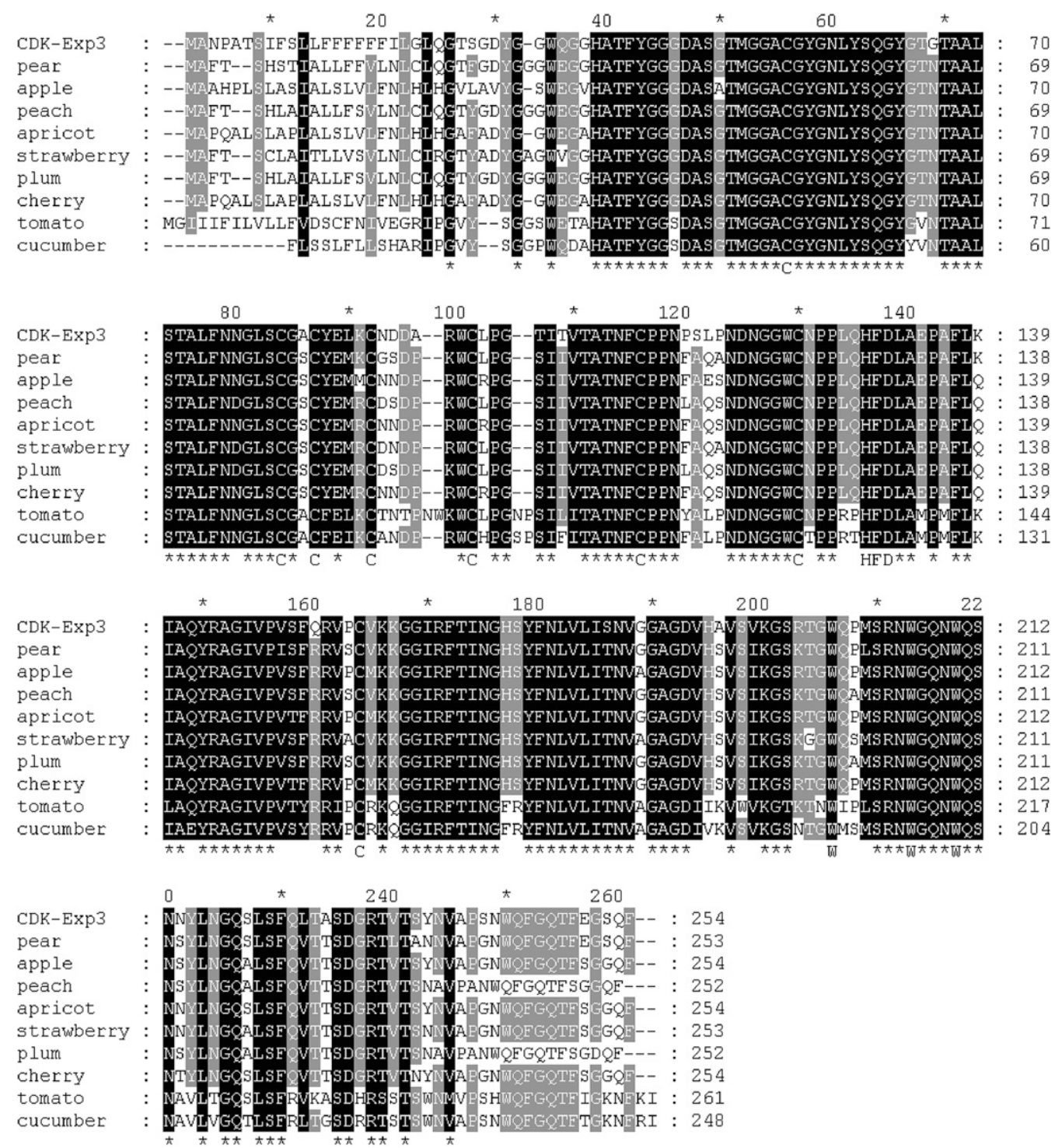

Fig. 1. Alignment of deduced amino acid sequence of persimmon fruit expansin $(C D K$-Exp3) in relation to other fruit species. The conserved regions are in the frame, and invariant residues are shaded. 
coding region. The clone was designated as $C D K$-Exp3 (accession number FJ455264).

Real-time polymerase chain reaction analysis. Two oligonucleotide primer pairs used for real-time PCR analysis were designed according to the sequence obtained in the present study using Primer 5.0 software (PREMIER Biosoft International, Palo Alto, CA). The primers are listed in Table 1. PCR was performed in an iCycler iQ real-time PCR instrument (Bio-Rad, Hercules, CA) in a total volume of $20 \mu \mathrm{L}$ containing $1 \mu \mathrm{L}$ of cDNAs, $0.8 \mu \mathrm{L}$ of each primer, and $10 \mu \mathrm{L}$ of $2 \times \mathrm{SYBR}$ Green PCR Master Mix (Takara, Dalian, China) with a predenaturation step at $95^{\circ} \mathrm{C}$ for 3 min followed by 40 amplification cycles at $95{ }^{\circ} \mathrm{C}$ for $30 \mathrm{~s}, 56{ }^{\circ} \mathrm{C}$ for $30 \mathrm{~s}$, and $72{ }^{\circ} \mathrm{C}$ for $30 \mathrm{~s}$. At the end of the PCR run, a melting curve was generated and analyzed. The housekeeping gene encoding actin was selected as an internal control to normalize the input amount of templates. For each sample, reactions were set up in triplicate. No template control for each primer pair was included in each run.

Statistical analysis. Data were subjected to repeated-measures analysis of variance (ANOVA) using SAS statistical software (Version 8; SAS Institute, Cary, NC). Fisher's least significant differences $(P=0.05)$ were determined to compare differences between means after a significant ANOVA effect. Data are presented as the mean \pm SEM.

\section{Results}

Sequence analysis. cDNA clones of $C D K$ Exp3 1168 bp in length were isolated from persimmon fruit at the full ripe stage. Analysis of the $C D K-\operatorname{Exp} 3$ sequence revealed a putative open reading frame of $765 \mathrm{bp}$ starting with an ATG codon encoding a polypeptide of 254 amino acid residues. The sequence of $C D K$ Exp3 showed a high amino acid homology to other fruit-specific expansins (Fig. 1). Apart from the signal sequence, $C D K-\operatorname{Exp} 3$ contains 8-cysteine (C) residues, four tryptophan (W) residues, and a His-Phe-Asp domain, which are characteristic of most $\alpha$-expansins (Fig. 1). Persimmon CDK-Exp3 had amino acid similarity of $82 \%, 82 \%, 81 \%, 80 \%, 80 \%, 80 \%$, $79 \%, 73 \%$, and $65 \%$ to apricot, cherry, pear, peach, plum, apple, strawberry, cucumber, and tomato fruits, respectively.

As shown in Figure 2, deduced ripeningspecific expansin proteins fall into two major phylogenetic branches: one consisted of cucumber FJ269042 and tomato U8123 and the second contained the other sequences. $C D K$ Exp3 clustered with $\alpha$-expansins within the expansin superfamily and was closely related to AY083166 (apple), AF350937 (cherry), U9316 (apricot), AB093029 (pear), AF159563 (strawberry), EU340362 (plum), and AB029083 (peach).

Firmness. As shown in Figure 3, control 'Fupingjianshi' persimmon fruit softened rapidly during ripening, from an initial value of $109.1 \pm 5.7$ to $24.2 \pm 1.4 \mathrm{~N} / \mathrm{cm}^{2}$ after $20 \mathrm{~d}$ storage. Softening was inhibited by $\mathrm{GA}_{3}$, firmness being $44 \%$ higher than that of control fruit from 4 to through $20 \mathrm{~d}$ of storage. At $28 \mathrm{~d}$,
$\mathrm{GA}_{3}$-treated fruit softened to levels comparable to the value of control fruit at $20 \mathrm{~d}$ (Fig. 3).

Ethylene production. Ethylene production in persimmon fruit at the start of the experiment averaged $8.25 \pm 0.79 \mathrm{ng} \cdot \mathrm{kg}^{-1} \cdot \mathrm{min}^{-1}$. The ethylene production in control fruit increased sharply to a climacteric maximum of $23.95 \pm 1.77 \mathrm{ng} \cdot \mathrm{kg}^{-1} \cdot \mathrm{min}^{-1}$ at $8 \mathrm{~d}$ followed by a fast decline as fruit ripened (Fig. 4). $\mathrm{GA}_{3}$ exhibited a strong suppression of ethylene

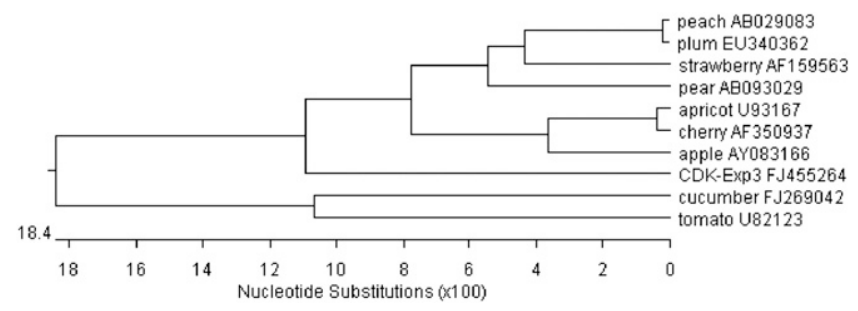

Fig. 2. Phylogenetic tree analysis of the deduced amino acid sequences of $C D K$-Exp3.

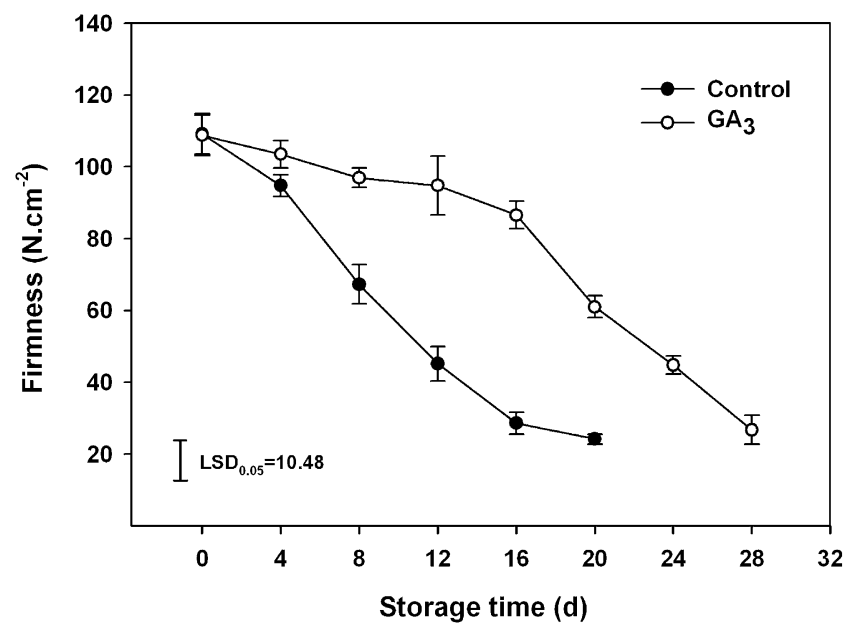

Fig. 3. Firmness of persimmon fruit during storage at $20^{\circ} \mathrm{C}$ after treatment with $60 \mathrm{mg} \cdot \mathrm{L}^{-1}$ gibberellic acid $\left(\mathrm{GA}_{3}\right)$ for $1 \mathrm{~min}$ at $20^{\circ} \mathrm{C}$. Fruit immersed in water served as control. Values are the means $\pm \mathrm{SE}$ of 10 individual fruit. Vertical bars represent the SES of the means.

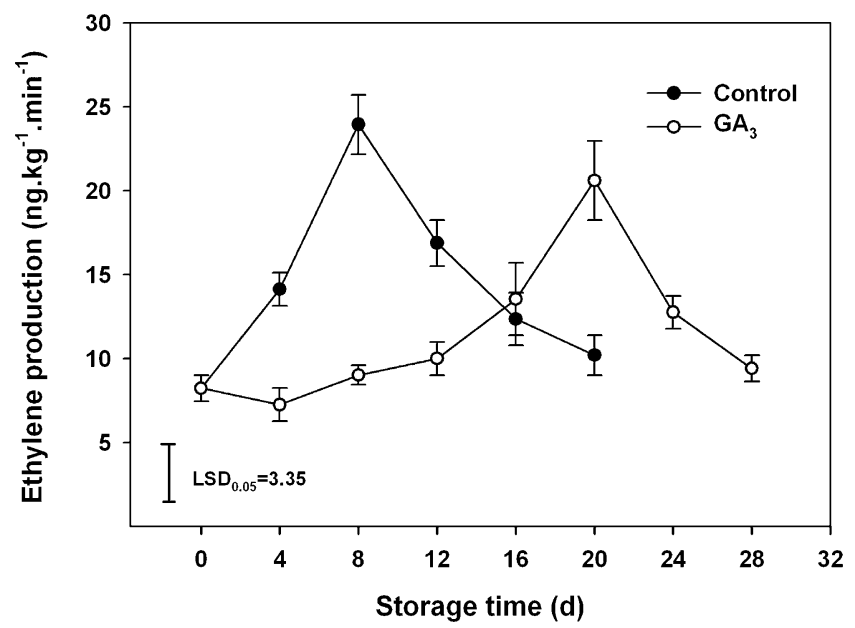

Fig. 4. Ethylene production of persimmon fruit during storage at $20{ }^{\circ} \mathrm{C}$ after treatment with $60 \mathrm{mg} \cdot \mathrm{L}^{-1}$ gibberellic acid $\left(\mathrm{GA}_{3}\right)$ for $1 \mathrm{~min}$ at $20^{\circ} \mathrm{C}$. Fruit immersed in water served as control. Values are the means \pm SE of five individual fruit. Vertical bars represent the SES of the means. 


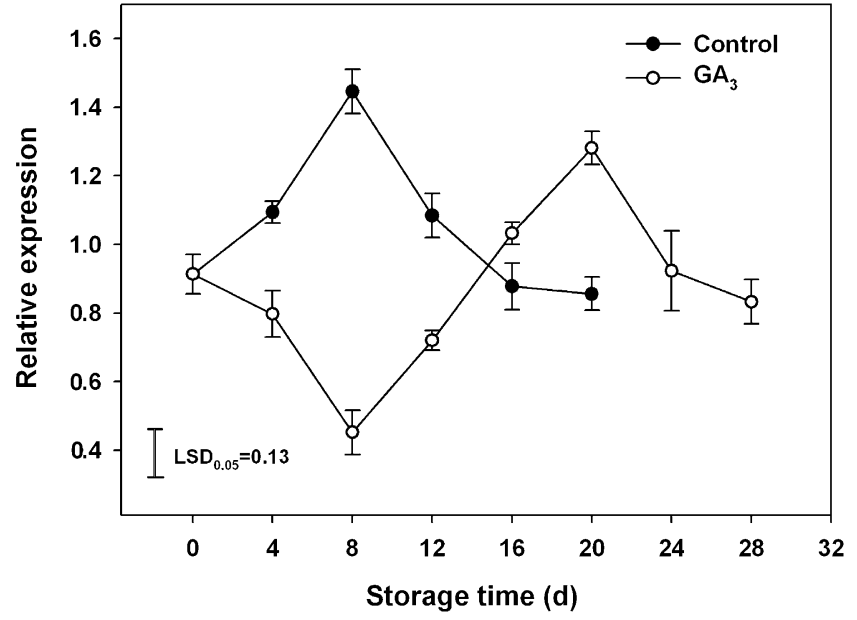

Fig. 5. Expression of expansin gene $(C D K-\operatorname{Exp} 3)$ of persimmon fruit during storage at $20^{\circ} \mathrm{C}$ after treatment with $60 \mathrm{mg} \cdot \mathrm{L}^{-1}$ gibberellic acid $\left(\mathrm{GA}_{3}\right)$ for $1 \mathrm{~min}$ at $20^{\circ} \mathrm{C}$. Fruit immersed in water served as control. All real-time polymerase chain reactions were normalized using the $\mathrm{Ct}$ value corresponding to the persimmon actin gene. Values are the means \pm SE of triplicate assays. Vertical bars represent the SES of the means.

$8 \mathrm{~d}$ of ripening. After $8 \mathrm{~d}$, expression of $C D K$ Exp3 gradually increased and reached a maximum at $20 \mathrm{~d}$, thereafter declining (Fig. 5).

\section{Discussion}

Expansins are broadly distributed in different plant tissues and exhibit distinct expression profiles relating to either fruit size or ripening stage of fruit (Brummell et al., 1999; Hiwasa et al., 2003). The ripening-related expansins, generally regarded as $\alpha$-expansins, may play a role in fruit softening through enhancing the accessibility of cell wall polymers to hydrolytic enzymes (Rose et al., 1997). In the present study, a softening-related expansin gene clone, $C D K-\operatorname{Exp} 3$, was identified in persimmon fruit during ripening, which encodes 254 amino acid residues compared with 177 residues of $C D K$-Exp1 and 174 residues of $C D K$-Exp2 in 'Fupingjianshi' persimmon (Tong et al., 2005). The characteristic domains in most of the $\alpha$-expansins are conserved in $C D K-\operatorname{Exp} 3$ at the respective positions, which probably involves disulfide bridges for protein conformation and protein-polysaccharide binding (Brummell and Harpster, 2001). The $C D K$-Exp 3 showed a high homology with other ripening-specific expansin genes in fruits including pear, apple, peach, apricot, strawberry, plum, and cherry (Fig. 1), suggesting that ripening-related expansins might possess common structural and functional characteristics in different fruit. In addition, $C D K-\operatorname{Exp} 3$ expressed abundantly when softening initiated and attained a high level within a few days (Fig. 5). We suggest that $C D K$ Exp3 as a promoter might play a crucial role for softening of persimmon fruit.

$\mathrm{GA}_{3}$, one of the important plant hormoneregulating growth and elongation of cells, can result in delayed ripening and resistance against fungus in strawberry (Given et al., 1988) and persimmon fruit (Ben-Arie et al., 1986; Eshel et al., 2000; Huang et al., 2006). The findings presented here showed that $\mathrm{GA}_{3}$ delayed the expression of $C D K-E x p 3$ of persimmon fruit during ripening and strongly suppressed softening and ethylene production. It is explicit that $C D K-\operatorname{Exp} 3$ may be an ethylene and ripening-related expansin. Such an ethylenedependent response has also been observed previously in MiExpA1 of mango in which expression of expasins was stimulated by ethylene within a short time and suppressed by an inhibitor of ethylene perception, 1methylcyclopropene (Sane et al., 2005).

In conclusion, a full-length expansin gene, $C D K-\operatorname{Exp} 3$, was identified from persimmon fruit in the present study, and the expression at the transcriptional level was associated with postharvest fruit softening. Regulation of the expansin gene by $\mathrm{GA}_{3}$ provides improved understanding for the manipulation of softening in persimmon.

\section{Literature Cited}

Asha, V., A. Sane, A.P. Sane, and P. Nath. 2007. Multiple forms of $\alpha$-expansin genes are expressed during banana fruit ripening and development. Postharvest Biol. Technol. 45:184-192.

Ben-Arie, R., H. Bazak, and A. Blumenfeld. 1986 Gibberellin delays harvest and prolongs storage life of persimmon fruits. Acta Hort. 179:807813

Brummell, D.A. and M.H. Harpster. 2001. Cell wall metabolism in fruit softening and quality and its manipulation in transgenic plants. Plant

Brummell, D.A., M.H. Harpster, and P. Dunsmuir. 1999. Differential expression of expansin gene family members during growth and ripening of tomato fruit. Plant Mol. Biol. 39:161-191.

Brummell, D.A., W.J. Howie, C. Ma, and P. Dunsmuir. 2002. Postharvest fruit quality of transgenic tomatoes suppressed in expression of a ripening-related expansin. Postharvest Biol. Technol. 25:209-220.

Civello, P.M., A.L.T. Powell, A. Sabehat, and A.B. Bennett. 1999. An expansin gene expressed in ripening strawberry fruit. Plant Physiol. 121: 1273-1279.

Eshel, D., R. Ben-Arie, A. Dinoor, and D. Prusky. 2000. Resistance of gibberellin- treated persimmon fruit to Alternaria alternata arises from the reduced ability of the fungus to produce Mol. Biol. 47:311-339. endo-1,4- $\beta$-glucanase. Phytopathology 11 $1256-1262$

Gaete-Eastman, C., C.R. Figueroa, C. Balbontín, M. Moya, R.G. Atkinson, R. Herrera, and M.A. Moya-León. 2009. Expression of an ethylenerelated expansin gene during softening of mountain papaya fruit (Vasconcellea pubescens). Postharvest Biol. Technol. 53:58-65.

Given, N.K., M.A. Venis, and D. Grierson. 1988 Hormonal regulation of ripening in the strawberry, a non-climacteric fruit. Planta 174:402406.

Goulao, L.F. and C.M. Oliveira. 2008. Cell wall modifications during fruit ripening: When a fruit is not the fruit. Trends Food Sci. Technol. 19:4-25.

Hayama, H., A. Ito, T. Moriguchi, and Y. Kashimura 2003. Identification of a new expansin gene closely associated with peach fruit softening. Postharvest Biol. Technol. 291:1-10.

Hiwasa, K., J.K.C. Rose, R. Nakano, A. Inaba, and Y. Kubo. 2003. Differential expression of seven $\alpha$-expansin genes during growth and ripening of pear fruit. Physiol. Plant. 117:564-572.

Huang, S., J.S. Zhang, and Y.M. Zhang. 2006. Effect of $\mathrm{GA}_{3}$ treatment on ethylene biosynthesis in post-harvested persimmon Fruits. Chi Agri. Sci. Bull. 22:88-90 [in Chinese with English abstract].

Li, Y., L. Jones, and S.J. McQueen-Mason. 2003. Expansins and cell growth. Curr. Opin. Plant Biol. 6:1-8.

McQueen-Mason, S.J. and D.J. Cosgrove. 1995. Expansin mode of action on cell walls. Analysis of wall hydrolysis, stress relaxation, and binding. Plant Physiol. 107:87-100.

McQueen-Mason, S.J., D.M. Durachko, and D.J. Cosgrove. 1992. Two endogenous proteins that induce cell wall extension in plants. Plant Cell 4:1425-1433.

Payasi, A., M.N. Nagendra, A.L.S. Chaves, and R. Singh. 2009. Biochemistry of fruit softening: An overview. Physiol. Mol. Biol. Plants 15:103113

Rose, J.K.C. and A.B. Bennett. 1999. Cooperative disassembly of the cellulose- xyloglucan network of plant cell walls: Parallels between cell expansin and fruit ripening. Trends Plant Sci. 4:176-183.

Rose, J.K.C., D.J. Cosgrove, P. Albersheim, A.G Darvill, and A.B. Bennett. 2000. Detection of expansin proteins and activity during tomato fruit ontogeny. Plant Physiol. 123:1583-1592.

Rose, J.K.C., H.H. Lee, and A.B. Bennett. 1997. Expression of a divergent expansin gene is fruit-specific and ripening-regulated. Proc. Natl. Acad. Sci. USA 94:5955-5960.

Sane, V.A., A. Chourasia, and P. Nath. 2005. Softening in mango (Mangifera indica cv. Dashehari) is correlated with the expression of an early ethylene responsive, ripening related expansin gene, MiExpA1. Postharvest Biol. Technol. 38:223-230

Tong, B., J.P. Rao, X.L. Ren, and J.R. Li. 2005 Cloning and sequencing of expansin cDNA in the fruits of Chinese persimmon. Acta Bot. Boreal.-Occident. Sin. 25:2168-2171 [in Chinese with English abstract]

Yang, S.L., C.D. Sun, P. Wang, L.L. Shan, C. Cai, B. Zhang, W.S. Zhang, X. Li, I.B. Ferguson, and K.S. Chen. 2008. Expression of expansin genes during postharvest lignification and softening of 'Luoyangqing' and 'Baisha' loquat fruit under different storage conditions. Postharvest Biol. Technol. 49:46-53.

Yang, S.L., C.J. Xu, B. Zhang, X. Li, and K.S Chen. 2007. Involvement of both subgroups A and $\mathrm{B}$ of expans in genes in kiwifruit ripening. HortScience 42:315-319. 